\title{
Article/Artigo
}

\section{Antimicrobial Resistance of Shigella spp. isolated in the State of Pará, Brazil}

\author{
Resistência Antimicrobiana de Shigella spp. isoladas no Estado do Pará
}

Flávia Corrêa Bastos ${ }^{1,2}$ and Edvaldo Carlos Brito Loureiro ${ }^{1}$

\begin{abstract}
Introduction: Shigella spp. are Gram-negative, nonsporulating, rod-shaped bacteria that belong to the family Enterobacteriaceae and are responsible for shigellosis or bacillary dysentery, an important cause of worldwide morbidity and mortality. Methods: We studied the antibiotic resistance profiles of 122 Shigella spp. strains ( 81 S. flexneri, 41 S. sonnei, 1 S. boydii) isolated from patients (female and male from 0 to 80 years of age) presenting diarrhea in different districts of the State of Pará, in the North of Brazil. The antibiotic resistance of the strains, isolated from human fecal samples, was determined by the diffusion disk method and by using the VITEK-2 system. Results: The highest resistance rate found was the resistance rate to tetracycline (93.8\%), followed by the resistance rate to chloramphenicol (63.9\%) and to trimethoprim/sulfamethoxazole (63.1\%). Resistance to at least three drugs was more common among S. flexneri than S. sonnei (39.5\% vs. 10\%). Six (4.9\%) strains were susceptible to all the antibiotics tested. All strains were susceptible to cefotaxime, ceftazidime, ciprofloxacin, nalidixic acid and nitrofurantoin. Conclusions: High rates of multidrug resistance in Shigella spp. are a serious public health concern in Brazil. It is extremely important to continuously monitor the antimicrobial resistances of Shigella spp. for effective therapy and control measures against shigellosis.
\end{abstract}

Keywords: Shigella spp. State of Pará. Antimicrobial resistance. Diarrhea.

\begin{abstract}
RESUMO
Introdução: Shigella spp. são bactérias Gram-negativas, não esporuladas, em forma de bastonete, pertencentes a família Enterobacteriaceae responsáveis pela shigelose ou disenteria bacilar, uma importante causa de mortalidade e morbidade mundial. Métodos: Foi estudado o perfil de resistência a antimicrobianos de 122 amostras de Shigella spp. (81 S. flexneri, 41 S. sonnei, 1 S. boydii) isoladas de pacientes (sexo feminino e masculino com faixa etária de 0 a 80 anos) com distúrbios gastrointestinais em diferentes municípios no Estado do Pará, Brasil. A resistência antimicrobiana das amostras isoladas de coprocultura, foi determinada pelo método de difusão em disco e pelo sistema Vitek II. Resultados: A maior resistência foi observada em relação à tetraciclina (93,8\%), seguida de cloranfenicol $(63,9 \%)$, e trimetoprimsulfametoxazol (63,1\%). Multirresistência a pelo menos três antimicrobianos foi mais comum em S. flexneri comparada a S. sonnei (39,5\% vs. 10\%). Seis (4,9\%) amostras foram sensíveis a todos antimicrobianos testados. Todas as amostras apresentaram sensibilidade a cefotaxima, ceftazidima, ciprofloxacina, ácido nalidixico e nitrofurantoína. Conclusões: As altas taxas de multirresistência de Shigella spp. são um sério problema de saúde pública no Brasil. Sendo assim, torna-se extremamente importante um monitoramento contínuo da resistência antimicrobiana de Shigella spp. para uma terapia efetiva e medidas de controle contra shigelose.
\end{abstract}

Palavras-chaves: Shigella spp. Estado do Pará. Resistência antimicrobiana. Diarréia.

1. Departamento de Bacteriologia e Micologia, Instituto Evandro Chagas, Ananindeua, PA. 2. Programa de Pós-Graduação em Biologia de Agentes Infecciosos e Parasitários, Universidade Federal do Pará, Belém, PA. Address to: Dra. Flávia Corrêa Bastos. Dept ${ }^{\circ}$ Bacteriologia e Micologia/IEC. Rodovia BR 316, Km $7 \mathrm{~s} / \mathrm{n}$, 67030-000 Ananindeua, PA, Brasil.

Phone: 5591 3214-2122; Fax 5591 3214-2128

e-mail: flavia_bastos@hotmail.com

Received in $26 / 01 / 2011$

Accepted in 28/02/2011

\section{INTRODUCTION}

Shigella spp. are Gram-negative, nonsporulating, rod-shaped bacteria that belong to the family Enterobacteriaceae. The bacteria are facultative intracellular pathogens that show a high specificity for primate hosts. Shigella spp., the human pathogens responsible for shigellosis, are highly infectious, even at low counts $\left(10^{2}\right)^{1}$. Shigellosis is recognized by the World Health Organization as a major, global, public health concern ${ }^{2}$. It is responsible for morbidity and mortality in high risk populations, such as children under five years of age, senior citizens, toddlers in day-care centers, patients in custodial institutions, homosexual men, those affected by war and famine and patients with chronic disease (e.g., HIV), predominantly in developing countries ${ }^{3}$. Shigellosis is an acute intestinal infection the symptoms of which can range from mild, watery diarrhea to severe, inflammatory bacillary dysentery characterized by strong abdominal cramps, fever and stools containing blood and mucus ${ }^{4}$. The disease is usually self-limiting but may become life-threatening if patients are immunocompromised or adequate medical care is not available. A combination of oral rehydration and antibiotics leads to rapid resolution of infection. Unfortunately, Shigella spp. have become resistant to commonly used antibiotics, drastically reducing therapeutic possibilities, especially in children ${ }^{5-6}$.

The genus Shigella includes four species: S. dysenteriae (serogroup A), S. flexneri (serogroup B), S. boydii (serogroup C), and S. sonnei (serogroup D). S. flexneri is the most common Shigella species in developing countries. In developed countries, S. sonnei is the most prevalent ${ }^{7}$. S. dysenteriae is implicated in epidemic disease outbreaks, the most severe form of dysentery and the majority of the fatal shigellosis cases ${ }^{8}$.

This study was conducted to identify the antimicrobial resistance profile of 122 strains of Shigella spp. (81 S.flexneri, 40 S. sonnei and 1 S. boydii) isolated during 1979-2009 from patients (male and female, from 0 to 80 years of age) who presented with diarrhea and were assisted at the Evandro Chagas Institute (IEC) in the State of Pará, Brazil. 


\section{METHODS}

\section{Bacterial strains}

From January 1979 to July 2009, many samples of 122 Shigella strains (81 S.flexneri, 40 S. sonnei and 1 S. boydii) were isolated from the clinical specimens of different patients (male and female from 0 to 80 years of age) presenting with diarrhea and assisted at the Bacteriology and Mycology Department of the IEC. The patients included in the study were from nine different districts in the State of Pará: Abaetetuba, Ananideua, Belém, Benevides, Castanhal, Icoaraci, Marabá, Marituba and Moju. The isolates, which belong to the bacterial collection of the IEC, were stored at $-70^{\circ} \mathrm{C}$ in Luria Bertani (LB) broth with $15 \%$ glycerol and at environmental conditions.

\section{Determination of antibiotic resistance}

Ampicilin (4, 8, and $32 \mu \mathrm{g} / \mathrm{mL})$, amoxilin (4/2, 16/8, and $32 / 16 \mu \mathrm{g} / \mathrm{mL})$, ceftazidime $(1,2,8$, and $32 \mu \mathrm{g} / \mathrm{mL})$, ciprofloxacin $(0,5,2$, and $4 \mu \mathrm{g} / \mathrm{mL})$, nalidixic acid $(8,16$, and $32 \mu \mathrm{g} / \mathrm{mL})$, nitrofurantoin $(16,32$, and $64 \mu \mathrm{g} / \mathrm{mL})$, and trimethoptim/ sulfamethoxazole $(0.5 / 9.5,2 / 38$, and $16 / 304 \mu \mathrm{g} / \mathrm{mL})$ were used to determine the resistance profiles of all Shigella strains studied using the VITEK-2 system (bioMérieux, Marcy I’Etoile, France). Thechloramphenicol $(30 \mu \mathrm{g})$, cefotaxime $(30 \mu \mathrm{g})$, gentamicin $(10 \mu \mathrm{g})$ and tetracycline $(30 \mu \mathrm{g})$ profiles of antibiotic resistance were determined by the diffusion disk method according to the Manual of the Clinical and Laboratory standards Institute (CLSI 2009) ${ }^{9}$. The standard reference strains of Escherichia coli ATCC 25922 and Pseudomonas aeruginosa ATCC 27,853 were used as controls throughout the study.

\section{RESULTS}

The resistances of the Shigella spp. strains to all the antimicrobials tested are shown in Table 1. A total of 115 (94.2\%) were resistant strains. The highest resistance rate found was the resistance rate to tetracycline (93.4\%), followed by the rate to chloramphenicol (63.9\%) and to trimethoptim/sulfamethoxazole (63.1\%). Sixty (49.2\%) strains were multidrug-resistant (resistant to at least two antimicrobials).

A total of 7 (5.8\%) strains were susceptible to all the antibiotics tested. All the strains were susceptible to cefotaxime, ceftazidime, ciprofloxacin, nalidixic acid and nitrofurantoin.

The antimicrobial resistance patterns of all the strains of Shigella spp. were compared to each other. Overall, $93.8 \%$ of the S. flexneri strains and $95 \%$ of S. sonnei strains were resistant to tetracycline. Seventy-five percent of the $S$. flexneri strains and $42.5 \%$ of the S. sonnei strains were resistant to chloramphenicol. Sixty-four percent of the S. flexneri strains and $62.5 \%$ of the $S$. sonnei strains were resistant to trimethoprim-sulfamethoxazole.

As shown in Table 2, only 39.5\% of the S. flexneri strains were resistant to at least three of the antibiotics (AM, C, SXT) tested.

TABLE 1 - Antimicrobial resistance of Shigella spp. strains by species.

\begin{tabular}{|c|c|c|c|c|c|c|c|c|}
\hline \multirow[b]{3}{*}{ Antimicrobial agent } & \multicolumn{8}{|c|}{ Number resistant to antimicrobials/percent } \\
\hline & \multicolumn{2}{|c|}{ total $(\mathrm{n}=122)$} & \multicolumn{2}{|c|}{ Shigella boydii $(\mathrm{n}=1)$} & \multicolumn{2}{|c|}{ Shigella flexneri $(\mathrm{n}=81)$} & \multicolumn{2}{|c|}{ Shigella sonnei $(\mathrm{n}=40)$} \\
\hline & $\mathrm{n}$ & $\%$ & $\mathrm{n}$ & $\%$ & $\mathrm{n}$ & $\%$ & $\mathrm{n}$ & $\%$ \\
\hline Ampicilina & 53 & 43.4 & 0 & 0.0 & 46 & 56.8 & 7 & 17.5 \\
\hline Amoxilin & 1 & 0.9 & 0 & 0.0 & 1 & 1.2 & 0 & 0.0 \\
\hline Cefotaxime & 0 & 0.0 & 0 & 0.0 & 0 & 0.0 & 0 & 0.0 \\
\hline Ceftazidima & 0 & 0.0 & 0 & 0.0 & 0 & 0.0 & 0 & 0.0 \\
\hline Chloramfenicol & 78 & 63.9 & 0 & 0.0 & 61 & 75.3 & 17 & 42.5 \\
\hline Ciprofloxacin & 0 & 0.0 & 0 & 0.0 & 0 & 0.0 & 0 & 0.0 \\
\hline Gentamicin & 1 & 0.9 & 0 & 0.0 & 1 & 1.2 & 0 & 0.0 \\
\hline Nalidixic acid & 0 & 0.0 & 0 & 0.0 & 0 & 0.0 & 0 & 0.0 \\
\hline Nitrofurantoin & 0 & 0.0 & 0 & 0.0 & 0 & 0.0 & 0 & 0.0 \\
\hline Tetracycline & 114 & 93.4 & 0 & 0.0 & 76 & 93.8 & 38 & 95.0 \\
\hline Trimethoprim/sulfametoxazole & 77 & 63.1 & 0 & 0.0 & 52 & 64.2 & 25 & 62.5 \\
\hline
\end{tabular}

TABLE 2 - Antimicrobial resistance patterns of Shigella spp. strains by species.

\begin{tabular}{|c|c|c|c|c|c|c|c|c|}
\hline \multirow[b]{3}{*}{ Resistance pattern } & \multicolumn{8}{|c|}{ Number resistant to antimicrobials/percent } \\
\hline & \multicolumn{2}{|c|}{ total $(n=122)$} & \multicolumn{2}{|c|}{ Shigella boydii $(\mathrm{n}=1)$} & \multicolumn{2}{|c|}{ Shigella flexneri $(\mathrm{n}=81)$} & \multicolumn{2}{|c|}{ Shigella sonnei $(\mathrm{n}=40)$} \\
\hline & $\mathrm{n}$ & $\%$ & $\mathrm{n}$ & $\%$ & $\mathrm{n}$ & $\%$ & $\mathrm{n}$ & $\%$ \\
\hline $\mathrm{AM}, \mathrm{AMC}, \mathrm{C}, \mathrm{SXT}$ & 1 & 0.9 & 0 & 0.0 & 1 & 1.2 & 0 & 0.0 \\
\hline $\mathrm{AM}, \mathrm{C}, \mathrm{GN}, \mathrm{SXT}$ & 1 & 0.9 & 0 & 0.0 & 1 & 1.2 & 0 & 0.0 \\
\hline AM, C, SXT & 36 & 29.5 & 0 & 0.0 & 32 & 39.6 & 4 & 10.0 \\
\hline $\mathrm{AM}, \mathrm{C}$ & 8 & 6.5 & 0 & 0.0 & 8 & 9.9 & 0 & 0.0 \\
\hline AM, SXT & 5 & 4.0 & 0 & 0.0 & 3 & 3.7 & 2 & 5.0 \\
\hline C, SXT & 8 & 6.5 & 0 & 0.0 & 7 & 8.7 & 1 & 2.5 \\
\hline C, TE & 1 & 0.9 & 0 & 0.0 & 1 & 1.2 & 0 & 0.0 \\
\hline $\mathrm{AM}$ & 2 & 1.6 & 0 & 0.0 & 1 & 1.2 & 1 & 2.5 \\
\hline $\mathrm{C}$ & 23 & 18.9 & 0 & 0.0 & 11 & 13.6 & 12 & 30.0 \\
\hline SXT & 26 & 21.3 & 0 & 0.0 & 8 & 9.9 & 18 & 45.0 \\
\hline $\mathrm{TE}$ & 4 & 3.2 & 0 & 0.0 & 4 & 4.9 & 0 & 0.0 \\
\hline No resistance & 7 & 5.8 & 1 & 100.0 & 4 & 4.9 & 2 & 5.0 \\
\hline
\end{tabular}

AM: ampicilin, AMC: amoxilin, C: chloramfenicol, SXT: trimethoprim/sulfametoxazole, GN: gentamicin, TE: tetracycline. 
The most common antimicrobial resistance pattern observed was resistance to ampicillin, chloramphenicol and trimethoprimsulfamethoxazole. Forty-five percent of the S. sonnei strains were resistant to only one antibiotic (trimethoprim-sulfamethozole). Resistance to at least three drugs (AM, C, SXT) was more common among S. flexneri than S. sonnei (39.5\% vs. $10 \%)$.

\section{DISCUSSION}

It is well established that $S$. flexneri is the most commonly isolated species of the Shigella genus in developing countries, and its presence has been associated with inadequate sanitation; in contrast, S. sonnei predominates in developed countries but is predominantly involved in sporadic, common-source outbreaks. S. boydii was first detected in India, and up to now, it has rarely been found outside the Indian subcontinent ${ }^{10}$. The species of Shigella most frequently isolated in Brazil, mainly from children under 5 years of age, are S. flexneri and S. sonnei ${ }^{7}$. Research on the epidemiology and microbiological aspects of bacterial diarrhea in children from Salvador in the State of Bahia, Brazil, demonstrated that in the period from January of 2002 to December of 2003, 1,991 patients between 0 and 15 years of age had their stools cultured, of which 260 presented bacterial growth. Shigella spp. were the most common pathogens and were found in 141 (54.3\%) cultures, of which $80.1 \%$ were identified as S. sonnei and $19.9 \%$ as S. flexneri ${ }^{11}$. The first study of gastroenteritis in the Amazonian area was accomplished in Santarém in the State of Pará, where $48 \%$ of the 320 patients with severe diarrhea were determined to have shigellosis ${ }^{12}$. In the period from 1979 to 1980 , investigations were conducted at private clinics and in a public hospital in Belém, State of Pará, Brazil with the objective of establishing the role of enteropathogenic bacteria as the cause of acute diarrhea in children from 0 to 5 years of age. They found Shigella in $13 \%$ of the cases (S. flexneri [62\%], S. sonnei [29\%], S. boydii [6\%] and S. dysenteriae [3\%] $)^{13}$. In the present study, most of the strains identified were $S$. flexneri (66.4\%) as well, followed by S. sonnei (32.8\%) and S. boydii (0.8\%).

The antibiotic resistance of Shigella spp. has been hindering the treatment of shigellosis, particularly in children ${ }^{5-6}$. A study conducted in the United States, involving 1,604 Shigella spp. strains isolated in the period from 1999 to 2002, revealed a high resistance $(1,031 / 64 \%)$ to the antibiotics tested. The largest resistance $(322 / 31 \%)$ was observed to the combination of ampicillin, estreptomicin and tetracycline, followed by ampicillin, estreptomicin and sulfametoxazol (149/14\%) and ampicillin and estreptomicin (108/10\%). Resistance to ampicillin in combination with cloranfenicol, estreptomicina, tetracycline and sulfametoxazole, was observed in $8 \%$ (85) of the strains ${ }^{5}$.

From June 2006 to February 2009, all patients with shigellosis reported in New York City were interviewed. Their Shigella isolates were tested for antimicrobial susceptibility to examine the level of resistance and to identify risk factors for resistance. Analysis was conducted on two groups distinguished by a large outbreak that was documented during the data collection period. Of the 477 non-outbreak patients, 333 (70\%) reported taking an antibiotic for shigellosis. Thirty-six (11\%) patients were treated with an antibiotic to which their Shigella infection was resistant. Among this group, high levels of antimicrobial resistance were detected to ampicillin (68\%) and trimethoprim-sulfamethoxazole $(66 \%)^{14}$.
Most of the S. flexneri strains isolated from cases of bacillary dysentery in Campinas, State of São Paulo, Brazil were resistant to more than one of the antibiotics tested, and $90 \%$ were resistant to at least three antibiotics. The antibiotics to which the bacteria were most commonly resistant were ampicillin (83.3\%), chloramfenicol (70\%), and tetracycline (80\%). However, among the S. sonnei strains, resistance was observed to $2(70 \%)$ or $3(30 \%)$ antibiotics. Resistance to tetracycline was detected in $96.7 \%$ of the strains. Resistance to ampicillin (6.7\%) was also detected among these strains 7 .

A study conducted on strains of different species of Shigella from cases of diarrhea in the State of Rondonia, Brazil in the period from March of 2000 to March of 2002 found high resistance to trimethoprim/sulfametoxazole and ampicillin. S. flexneri was the only species that presented multidrug resistance ${ }^{9}$.

Our study revealed that Shigella spp. isolated in Belém, State of Pará, Brazil were resistant mostly to tetracycline (93.4\%), chloramfenicol (63.9\%), trimethoprin/sulfametoxazole (63.1\%) and ampicilin (43.4\%). No resistance was found to cefotaxime, ceftazidima, ciprofloxacin or nalidixic acid.

Because of increasing antimicrobial resistance in Shigella spp., empirical treatment options are decreasing. Antimicrobial therapy for shigellosis requires knowledge of the antimicrobial resistance patterns of the Shigella spp. strains circulating locally. Physicians should be aware of the high multidrug resistance rates of Shigella spp., especially resistance to tetracycline and chloramfenicol. S. flexneri is still the most prevalent species in many Brazilian cities, and its higher antimicrobial resistance rate compared to that of $S$. sonnei is a cause for concern.

It is extremely important to continuously monitor the antimicrobial resistances of Shigella spp. for effective therapy and control measures against shigellosis.

\section{CONFLICT OF INTEREST}

The authors declare that there is no conflict of interest.

\section{FINANCIAL SUPPORT}

This work was supported by the Conselho Nacional de Desenvolvimento Científico e Tecnológico (Cnpq) and the Evandro Chagas Institute, Ananindeua/Pará/Brazil.

\section{REFERENCES}

1. Small P, Blanjenhorn D, Welty D, Zinser E, SlonezewkiJL. Acid and base resistance in Escherichia coli and Shigella flexneri role of rpoS and growth pH. J Bacteriol 1994; 176:1729-1737.

2. Kotloff KL, Winickoff JP, Ivanoff B. Global burden of Shigella infections implications for vaccine development and implementation of control strategies. Bull World Health Organ 1999; 77:651-666.

3. Thong KL, Hoe SL, Puthucheary SD, Yasin RM. Detection of virulence genes in Malaysian Shigella species by multiplex PCR assay. BMC Infectious Dis 2005; 5:8.

4. Sansonetti PJ. Rupture, invasion and inflammatory destruction of the intestinal barrier by Shigella, making sense of prokaryote-eukaryote cross-talks. FEMS Microbiol Rev 2001; 25:3-14.

5. Sivapalasingam S, Nelson JM, Joyce K, Hoekstra M, Angulo FJ, Mintz ED High prevalence of antimicrobial resistance among Shigella isolates in the united States tested by the national antimicrobial resistance monitoring system from 1999 to 2002. Antimicrob Agents Chemother 2006; 50:49-54. 
6. Silva T, Nogueira PA, Magalhães GF, Grava AF, Silva LHP, Orlandi PP. Characterization of Shigella sp. by antimicrobial resistance and PCR detection of ipa genes in an infantile population from Porto Velho (Western Amazon region), Brazil. Mem Inst Oswaldo Cruz 2008; 103:731-733.

7. Penatti MPA, Hollanda LM, Nakazato G, Campos TA, Lancellotti M, Angellini M, et al. Epidemiological characterization of resistance and PCR typing of Shigella flexneri and Shigella sonnei strains isolated from bacillary dysentery cases in Southeast Brazil. Braz J Med Biol Res 2007; 40:249-258.

8. Löfdahl M, Ivarsson S, Andersson S, Långmark J, Plym-Forshell L. An outbreak of Shigella dysenteriae in Sweden, May-June 2009, with sugar snaps as the suspected source. Euro Surveill 2009; 14:28.

9. Centers for Disease Control and Prevention. National Antimicrobial Resistance Monitoring System annual report. Atlanta, USA: CDC; 2009.

10. Niyogi SK. Shigellosis. J Microbiol 2005; 43:133-143.

11. Diniz-Santos DR, Santana JS, Barretto JR, Andrade MGM, Silva LR. Epidemiological and microbiological aspects of acute bacterial diarrhea in children from Salvador, Bahia, Brazil. Braz J Infect Dis 2005; 9:77-83.

12. Maroja RC, Lowery WD. Estudos sobre diarréias agudas. II. Frequência de Shigella e Salmonella nos casos de diarréias agudas em Santarém-Pará. Revista FSESP 1956; 8:585-589.

13. Linhares AC, Monção HC, Gabbay YB, Araújo VLC, Serruya AC, Loureiro ECB. Acute diarrhoea associated with rotavirus among children living in Belém, Brazil. Trans R Soc Trop Med Hyg 1983; 77:384-390.

14. Wong MR, Reddy V, Hanson H, Johnson KM, Tsoi B, Cokes C, et al. Microb Drug Resist 2010; 16:155-161. 